1 Quantification and comparison of the reaction properties of FEBEX

2 and MX-80 clays with saponite, as immobilizers of europium under subcritical conditions.

\section{Abstract \\ Abstract}

The evaluation of the retention mechanisms in FEBEX and MX-80 bentonites, selected as reference materials to construct engineered barriers, carries major implications in the safe storage of nuclear waste. The kinetics and reactivity of the reaction of Eu -as a lanthanide high-level radioactive waste simulator- with FEBEX and MX-80 were investigated, in addition to their immobilisation capacity through a recently discovered chemical retention mechanism and the structural analysis of the reaction products. Hydrothermal treatments were accomplished with $\mathrm{Eu}\left(\mathrm{NO}_{3}\right)_{3}\left({ }^{151} \mathrm{Eu}\right.$ and ${ }^{153} \mathrm{Eu}$, with $\left.52.2 \%{ }^{153} \mathrm{Eu}\right)$ and spiked with radioactive ${ }^{152} \mathrm{Eu}$ for the quantification of the reactions. Results were compared with saponite as the reference smectite. The strong dependence of the reaction parameters with temperature and time was quantified and the reaction velocity was evaluated. The velocity follows these trends: 240 days are needed for the total retention of europium for temperatures over $200^{\circ} \mathrm{C}$; below $150^{\circ} \mathrm{C}$, significantly longer reaction times, on the order of three years are required to complete the reaction. Clays do not 
24 influence velocity rates, but the retention capacity of bentonites remains lower than for saponite.

25 At $300^{\circ} \mathrm{C}$, the milliequivalents retained by the three clays are consistently over CEC. The

26 structural analyses reveal not only adsorption of europium but also the presence of $\operatorname{Eu}(\mathrm{OH})_{3}$

27 precipitation and $\mathrm{Eu}_{2} \mathrm{SiO}_{3}$ confirming the existence of a chemical reaction.

28 Key Words: Bentonite, smectite, disilicates, europium, hydrothermal treatment, radioactive 29 waste.

\section{Introduction}

In many countries, the development of Deep Geological Repositories (DGR), for the storage

33 of high-level radioactive waste (HLRW) is based on a system of multiple barriers. Most safety

34 within the repositories relies on the engineered barrier (Savage and Chapman, 1982). Clays

35 present low permeability, and high sorption and swelling capacity, which makes them ideal

36 materials for natural and engineered barriers for nuclear waste isolation (Pusch, 2006). A clay

37 barrier is able to delay the diffusion and immobilise, in certain experimental conditions, the 38 radioactive wastes through a physical-chemical mechanism, such as adsorption, desorption or 39 even a chemical reaction including the formation of secondary stable mineral phases. At the 40 present time, bentonite is accepted as the most suitable clay for the engineered barrier in DGRs 41 (Fernandes et al., 2012).

42 The performance of clay as the main component of the engineered barrier in the DGR has 43 been intensively studied, e.g. its response to intense irradiation (Sorieul et al., 2008), its sorption 44 properties (Fernandes et al., 2012; Stumpf et al., 2001), colloid formation reactions (Bouby et al., 45 2011) and the connections between sorption chemistry and mechanical compaction (Miller and 46 Wang, 2012). Regarding the clay adsorption properties, recent studies highlight the existence of 47 an additional retention mechanism (Alba et al., 2009a; Trillo et al., 1994). The systematic study 
48 of the interaction of the Rare Earth Element (REE) cations, such as $\mathrm{La}, \mathrm{Lu}, \mathrm{Nd}, \mathrm{Sm}$, as actinides

49 chemical analogues, with natural and artificial clay minerals, reveal a reaction mechanism, based

50 on the chemical interaction between the lanthanide cations and the orthosilicate anions of the

51 lamellar structure (Alba et al., 2011; Alba and Chain, 2005). At subcritical conditions,

52 (temperature and pressure), an insoluble and chemically stable phase, $\mathrm{REE}_{2} \mathrm{Si}_{2} \mathrm{O}_{7}$, is generated

53 (Alba et al., 2009b). Therefore, the expected retention capacity of bentonite increases and can

54 provide a stable immobilisation mechanism even when its sorption and swelling capacities fail

55 (Alba and Chain, 2007).

56 These previous studies are focused on the structural analysis of $\mathrm{REE}_{2} \mathrm{Si}_{2} \mathrm{O}_{7}$, after the 57 hydrothermal reaction between REE cations and clay minerals (Alba and Chain, 2005; Alba and 58 Chain, 2007; Alba et al., 2009a). More recently, Alba et al., (2011) have quantified the Eu ${ }^{3+}$ 59 immobilization by a standard saponite, and physical and chemical interactions are analysed.

60 However, the final motivation of these analyses is the study of bentonites, since they constitute 61 one of the most recommended materials for the construction of the engineered barrier.

62 In this work, an evaluation of the retention mechanisms in bentonites is performed. The 63 FEBEX and MX-80 clays are commonly selected as reference materials by various nuclear waste 64 management agencies in the construction of engineered barriers in a potential DGR (Villar et al., 65 2012).

66 Therefore, the aims of this study are: i) quantification of the immobilisation power of the 67 bentonites FEBEX and MX-80 in comparison with the pure smectite saponite; ii) completion of a 68 kinetic analysis of the process and a structural analysis of the products of reaction; and iii) 69 verification of the mechanism in a wide range of temperatures, including those where the extent 70 of the reaction is so low that is not possible to detect structural changes. 
71 In order to achieve these objectives, hydrothermal treatments of FEBEX and MX-80 with

72 stable europium are performed in the temperature range between $80^{\circ} \mathrm{C}$ and $300^{\circ} \mathrm{C}$. Stable 73 europium was spiked with ${ }^{152} \mathrm{Eu}$ in order to quantitatively compare the reactivity and kinetics of

74 the bentonites to the saponite.

\section{Materials and methods}

2.1. Clay samples.

The FEBEX bentonite was extracted from the Cortijo de Archidona deposit (Almería, Spain).

80 The processing at the factory consisted of disaggregation and gently grinding, drying at $60{ }^{\circ} \mathrm{C}$ 81 and sieving by 5mm (ENRESA, 2000; ENRESA, 2006). The montmorillonite content of the

82 FEBEX bentonite was above 90\% (92 $\pm 3 \%$ )(Villar et al., 2012). The MX-80 bentonite was 83 extracted from Wyoming (USA) and was supplied in the form of powder homoionised with 84 sodium (Madsen, 1998). The MX-80 batch used in this investigation was mainly composed of 85 montmorillonite $(83 \%)$ (Villar et al., 2012). As reference, a purified saponite from the Source 86 Clay Minerals Repository of the University of Missouri (Columbia) was used as reference 87 material (Alba et al., 2001). Table 1 summarizes the main clay characteristics (Galunin et al., 88 2010).

$90 \quad$ 2.2. $\mathrm{Eu}^{3+}$ solutions.

91 Two sets of starting solutions of $7.9 \cdot 10^{-2} \mathrm{M} \mathrm{Eu}\left(\mathrm{NO}_{3}\right){ }_{3}\left({ }^{151} \mathrm{Eu}\right.$ and ${ }^{153} \mathrm{Eu}$, with $\left.52.2 \%{ }^{153} \mathrm{Eu}\right)$ 92 were prepared: The first solution contained solely stable Eu isotopes; the second solution was 93 enriched with the radioisotope ${ }^{152} \mathrm{Eu}$ (with a half-life of 13.5 years). A volume of $1 \mathrm{ml}$ from a 94 diluted standard solution up to a total activity of $9.8 \mathrm{~Bq}$ was added to $35 \mathrm{ml}$ of the former 
95 solution, as a compromise for safe radioactive handling and high counting rates for fast

96 measurements. That activity corresponded to $10^{-14}$ mol of ${ }^{152} \mathrm{Eu}$. The $\mathrm{pH}$ of the two solutions was

97 adjusted to $\mathrm{pH}=6.0-6.5$, by slowly adding $0.05 \mathrm{M}$ ammonia solution while stirring.

98

2.3. Hydrothermal treatments.

100 Three hundred milligrams of the powdered samples (Saponite, FEBEX, MX-80) were

101 dispersed in the $40 \mathrm{ml}$ of $\mathrm{Eu}^{3+}$ solutions and were heated in a stainless steel reactor (Perdigón,

102 2002), at the temperatures and times summarized in Table 2. The cells marked with vertical lines

103 correspond to the treatment with a starting solution of $7.9 \cdot 10^{-2} \mathrm{M} \mathrm{Eu}\left(\mathrm{NO}_{3}\right)_{3}$, while the grey cells

104 correspond to the treatment with a starting solution of $7.9 \cdot 10^{-2} \mathrm{M} \mathrm{Eu}\left(\mathrm{NO}_{3}\right)_{3}$ enriched with the

$105{ }^{152} \mathrm{Eu}$ isotope. The reaction products were collected by filtering using a Millipore filter with 0.45

$106 \mu \mathrm{m}$ pore diameter, washed with distilled water, and dried in air at $60^{\circ} \mathrm{C}$. The reaction solution and

107 the washing liquid were kept for quantitative analysis of europium by gamma spectroscopy. The

108 solid samples were collected either for gamma $\left({ }^{152} \mathrm{Eu}\right.$ spiked), or for structural analysis by XRD

109 and SEM/EDX (not spiked with radioactive isotopes).

110

111 2.4. Characterization methods.

112 A Canberra, hyper-pure n-type germanium gamma detector (HPGe), was used for ${ }^{152} \mathrm{Eu}$ 113 gamma spectrometry measurements, in Radioisotopes Service at CITIUS laboratories 114 (Universidad de Sevilla). Counting efficiency was experimentally determined by means of 115 preparing standards spiked with ${ }^{152} \mathrm{Eu}$ for the two geometries analysed: filter and cylindrical 116 beaker. Efficiency was verified for both counting geometries using Monte Carlo simulations, 117 through an optimized LABSOCS program (Hurtado and Villa, 2010). 
118 In the structural study, powered non- ${ }^{152} \mathrm{Eu}$ spiked samples were analysed using a Bruker D8

119 to obtain an X-Ray diffraction diagram (XRD), also located at CITIUS laboratories (Universidad

120 de Sevilla). Radiation of $\mathrm{Cu}, \mathrm{K} \alpha$, and Ni filters was chosen, whereby $40 \mathrm{kV}, 40 \mathrm{~mA}, 0.05^{\circ} 2 \theta$

121 step, and $3 \mathrm{~s}$ counting time were the operational parameters. Crystalline phase identification was

122 carried out using the DIFFRAC ${ }^{\text {plus }}$ Evaluation package (C2010 Bruker AXS GmbH, Karlsruhe,

123 Germany).

124 When crystalline phases could not be identified by XRD, scanning electron microscopy 125 (SEM/EDX) was chosen. Morphologies and chemical compositions were analysed in Microscopy

126 Service in ICMS (CSIC-Universidad de Sevilla) with a SEM-FEG HITACHI S- 4800; a scanning 127 electron microscope equipped with an Xflash 4010 (Bruker) for energy dispersive X-ray (EDX) 128 analysis.

\section{3. Results and discussion}

3.1. Quantification of the reactivity of clays with $\mathrm{Eu}^{3+}$.

133 Retention of europium in the bentonites was evaluated from the comparison of the initially 134 added radioactive europium with the measurement of the europium in the filter after 135 hydrothermal treatment. Subsequently, milliequivalents of europium per $100 \mathrm{~g}$ clay retained in the 136 solid were calculated and displayed for every hydrothermal treatment in Fig. 1, where the amount 137 of europium that would be needed to satisfy the CEC (Cation Exchange Capacity) of the clays 138 (horizontal lines) is also shown.

139 Predominantly, when the reaction temperature increases, the amount of europium retained in 140 the solid phase increases. At the beginning of the reaction $(\mathrm{t}=0)$, the milliequivalents of europium 141 retained by the clays were within the range of the CEC for every temperature, that is, the 
142 europium was retained exclusively due to cationic exchange, and no significant chemical reaction

143 took place. At $300^{\circ} \mathrm{C}$, for longer reaction times, regardless of the clay, the milliequivalents of

144 retained europium were higher than the CEC, that is, immobilization was not only associated to

145 sorption in specific and non-specific sites, but also to the chemical reaction between europium

146 and the clay framework. For the FEBEX and MX- 80 bentonites, the amount of europium

147 retained, although higher than CEC, was significantly lower than for saponite. At $150^{\circ} \mathrm{C}$, only

148 saponite was able to retain europium above its CEC, and hence the immobilization of europium

149 in FEBEX and MX-80 is associated exclusively to CEC for the first two months of the reaction.

150 At $80^{\circ} \mathrm{C}$, no clay was able to retain milliequivalents of europium above CEC.

151 One of the highlights of this work is that we have succeeded in quantitatively comparing

152 FEBEX and MX-80 in relation to the retention capacity of one key radionuclide. It was found

153 that the differences for the two clays were negligible in this respect, but their retention capacity,

154 either chemical or physical, was lower than that of the reference clay (saponite).

155 The immobilisation capacity of bentonites through the chemical retention mechanism is also 156 proved and quantified. This impact is highlighted at $300^{\circ} \mathrm{C}$, since at that temperature, the 157 milliequivalents retained were consistently over the CEC. For saponite, the europium reaction is 158 400-1200\% times higher. In FEBEX and MX-80, europium reacts from 130\% to 600\% (FEBEX), 159 and $130 \%$ to $1100 \%$ (MX-80) over the CEC. The chemical reaction failed to clearly increase with 160 time for every clay and every temperature. However, in the case of saponite, this increase did 161 remain clear. Since the retention of europium over CEC is a first order kinetical reaction (Alba et 162 al., 2011), it is expected that europium retention in the clays over their CEC capacities (formation 163 of new chemical phases) will be increased with longer reaction times (years).

164 These results could be critical in HLRW disposal within the engineered barrier, and carry 165 implications towards the stability of the radioactive wastes stored in bentonite since the formation 
166 of chemical phases is expected to be more stable than the sorption in non-specific sites of the

167 clay.

168

169 3.2. Reaction rate of $E u^{3+}$-clays.

170 The quantification of the reaction using radioactive ${ }^{152} \mathrm{Eu}$ supports previously found evidence

171 (Alba et al., 2011) that showed a strong dependence of the reacted europium and its reaction

172 velocity on temperature and time.

173 Figure 2 presents the results for the hydrothermal treatment with the clays at different

174 temperatures. The ratio in the ordinate of Figure 2 represents the ${ }^{152} \mathrm{Eu}$ measured in the solution,

175 (that is, unreacted ${ }^{152} \mathrm{Eu}$ ), referring to the total ${ }^{152} \mathrm{Eu}$ collected after the treatment, and was shown

176 versus time. In other words, ${ }^{152} \mathrm{Eu}$ is measured in clay and solution, and the total represents the

$177{ }^{152} \mathrm{Eu}$ involved in the reaction: reacted $\left({ }^{152} \mathrm{Eu}\right.$ measured within the clay) and unreacted $\left({ }^{152} \mathrm{Eu}\right.$

178 measured in the remaining solution). The europium amount in the remaining solution decreased

179 with time and temperature. The ${ }^{152} \mathrm{Eu}$ concentration in the solution (Fig. 2), which is directly

180 related to europium reactivity, was fitted to an exponential (first order kinetic reaction) with a

181 good regression coefficient, especially for higher temperatures and/or long reaction times (Table

182 3). The exponent of the fitting provided the reaction velocity constant, $k$, according to

$$
I=I_{0} e^{-k t}
$$

184 The $k$ values obtained from the exponential fitting for saponite, FEBEX, and for MX-80 at 185 various temperatures are displayed in Table 3. From the $k$ value, and by taking into account a 186 first-order reaction, the half-life of the reaction $\left(T_{1 / 2}=\ln 2 / k\right)$ was calculated and shown in 187 Table 3. 
The velocity rate $(k)$ depends on the temperature. At $350^{\circ} \mathrm{C} \leq \mathrm{T} \leq 200^{\circ} \mathrm{C}$, the velocity of the

189 reaction was relatively fast and the fitted exponentials showed steep slopes. Their reaction rate

190 constants, $k$, were also similar within the uncertainty (Table 3). $k$ values displayed in Table 3, can

191 be used to calculate the half-life of the exponential decay. Which is 49.5 days in this case.

192 According to the definition of half-life at least 5 half-lives are needed to consider that the

193 exponential decay approached approximately zero, i.e. around 8 months would be needed for the

194 total retention of the europium by the saponite.

195 On the other hand, at $150^{\circ} \mathrm{C}$ and $80^{\circ} \mathrm{C}$, the decay was slower and longer reaction times were

196 needed in order to evaluate the constant rate accurately; that is why the exponential fitting for

$197150^{\circ} \mathrm{C}$ and $80^{\circ} \mathrm{C}$ display poorer regression-fitting parameters ( $\mathrm{R}^{2}$ lower than 0.7$)$. An estimation

198 of the reaction constant was obtained for both temperatures, and despite the higher uncertainties,

199 it remains clear that the constant of the exponential fitting was significantly lower. Calculated $k$

200 values were one order of magnitude lower than for $\mathrm{T} \geq 200^{\circ} \mathrm{C}$ (Table 3). Lower $k$ values result in

201 longer reaction times (within three years) needed to complete the immobilisation of the 202 europium.

203 It is worth noticing that reaction velocities were classified in two groups of temperature (350$204200^{\circ} \mathrm{C}$ and $150-80^{\circ} \mathrm{C}$ ) and provided two distinct $k$ values for every group. Within the same 205 temperature, arranged $k$ velocities were indistinguishable, in accordance with the uncertainty.

206 Moreover, $k$ values quantified in Table 3 were equivalent for the three clays. Within 207 uncertainties, equivalent reaction velocities were observed for saponite, FEBEX and MX-80.

208 This implies that various types of clay affect the concentration of retained europium, but not their 209 reaction velocities. The time needed to complete the reaction is thus independent of the clay. To 210 immobilise all the europium at $300-350^{\circ} \mathrm{C}$, approximately $8-9$ months would be needed. The 
211 reaction time increases for lower temperatures; to immobilise all the europium at $80-150^{\circ} \mathrm{C}$,

212 several years would be needed.

213 In Alba et al. (2011) it is presented europium reaction with saponite (i.e. europium

214 immobilization by saponite) at $300^{\circ} \mathrm{C}, 200^{\circ} \mathrm{C}, 150^{\circ} \mathrm{C}$, and $80^{\circ} \mathrm{C}$. It increases with the temperature

215 and its reaction velocities are discriminated into two groups, according to the temperature. The

216 following relationship was found:

$217 \quad \mathrm{Eu}_{\text {reacted }}\left(350^{\circ} \mathrm{C}\right)>\mathrm{Eu}_{\text {reacted }}\left(200^{\circ} \mathrm{C}\right)>\mathrm{Eu}_{\text {reacted }}\left(150^{\circ} \mathrm{C}\right)>\mathrm{Eu}_{\text {reacted }}\left(80^{\circ} \mathrm{C}\right)$.

218 Figure 2 shows that for the three clays, the amount of unreacted europium at $300-350^{\circ} \mathrm{C}$ was

219 lower than at $150^{\circ} \mathrm{C}$ and $80^{\circ} \mathrm{C}$. Furthermore, at $300-350^{\circ} \mathrm{C}$, the amount of retained europium

220 clearly depended on the clay used in the reaction. The following relationship is thereby inferred

221 in terms of capacity of immobilisation of europium at $300^{\circ} \mathrm{C}$.

$$
\mathrm{Eu}_{\text {reacted }}(\text { saponite })>>\mathrm{Eu}_{\text {reacted }}(\mathrm{FEBEX})>\operatorname{Eu}_{\text {reacted }}(\mathrm{MX}-80)
$$

223 At $80^{\circ} \mathrm{C}$ and $150^{\circ} \mathrm{C}$, the trend was similar. At $150^{\circ} \mathrm{C}$, the points were scattered, although 224 saponite provided clearly higher reactivity values, and FEBEX and MX-80 provided 225 indistinguishable reactivity. Values seemed to be higher for MX-80, however this deduction 226 remains inconclusive due to the high uncertainties of the results. At $80^{\circ} \mathrm{C}$, the reactivity was 227 almost equal for all three clays, but could not be verified due to the high dispersion of the results.

\subsection{Structural studies.}

The XRD patterns of the bentonites and those after reaction with $7.9 \cdot 10^{-2} \mathrm{M} \mathrm{Eu}\left(\mathrm{NO}_{3}\right)_{3}$ at

$231300^{\circ} \mathrm{C}$ are displayed in Figs. $3 \mathrm{~b}$ and $4 \mathrm{~b}$. The pattern of the original bentonites (Figs. $3 \mathrm{a}$ and $4 \mathrm{a}$ )

232 show the general and basal reflections. The $h k$ bands are composed of asymmetrical reflections 233 with the characteristic "saw-tooth" shape of the two-dimensional reflections (Warren, 1941). The

234 basal reflections are symmetrical. The $14.6 \AA$ and $11.9 \AA \mathrm{d}_{001}$ values of unreacted FEBEX and 
235 MX-80 bentonite, respectively, corresponded mainly to the bilayer hydrated $\mathrm{Ca}^{2+}$ in the FEBEX

236 interlayer and to the monolayer hydrated $\mathrm{Na}^{+}$in the MX-80 interlayer (Alba et al., 2001; Grim,

237 1968; Ravina and Low, 1977; Warren, 1941).

238 After the hydrothermal reaction at $300^{\circ} \mathrm{C}$, (Figs. 3 and 4, b-f) the basal spacing of 239 bentonites was increased to $15.5 \AA$, in agreement with data reported for smectites saturated with 240 multivalent cations (Ravina and Low, 1977). This increase agreed with a sorption of $\mathrm{Eu}^{3+}$ 241 equivalent to its CEC at $0 \mathrm{~h}$ (see Fig. 1). At reaction times longer than $0 \mathrm{~h}$, where the sorption 242 was higher than the $\mathrm{CEC}$, small reflections in the $10-55^{\circ} 2 \theta$ range were observed as a 243 consequence of the generation of the new phases. In FEBEX, those small reflections 244 corresponded to $\mathrm{Eu}_{2} \mathrm{SiO}_{3}$ (PDF 35-297, marked with E), quartz (PDF 2-458, marked with q), $245 \mathrm{Na}_{8}\left(\mathrm{AlSiO}_{4}\right)_{6}(\mathrm{OH})_{2}\left(\mathrm{PDF} 40-0100\right.$, marked with a), and $\mathrm{Eu}(\mathrm{OH})_{3}$ (PDF 83-2305, marked with 246 oh). In MX-80, only $\mathrm{Eu}_{2} \mathrm{SiO}_{3}$ and quartz were detected; the absence of $\mathrm{Eu}(\mathrm{OH})_{3}$ could be due to 247 the final $\mathrm{pH}$ value being below 3. The XRD patterns were noisy and showed a prominent 248 background, which indicated the partial disruption of the bentonite framework.

249 The treatments at $150^{\circ} \mathrm{C}$ and $80^{\circ} \mathrm{C}$ caused no crystallization of new phases and the unique 250 change in the XRD patterns was the shift of the 001 reflexion towards higher $2 \theta$ degree. Figure 5 251 shows the XRD pattern of both bentonites after hydrothermal treatment at $80^{\circ} \mathrm{C}$ for 63 days and 252 at $150^{\circ} \mathrm{C}$ for 56 days. In both cases, the $2 \theta$ position of the 001 reflection indicates the basal 253 spacing of bentonites, increased up to $15.5 \AA$, in agreement with the sorption of $\mathrm{Eu}^{3+}$ at no 254 specific sites (Ravina and Low, 1977).

255 These results were corroborated through the compositional mapping by SEM/EDX of the 256 bentonites hydrothermally treated at $150^{\circ} \mathrm{C}$ (Fig. 6). In general, the morphology of most of the 257 particles were lamellar with amounts of $\mathrm{Si}, \mathrm{Al}$ and $\mathrm{Eu}$ compatible with bentonites saturated with $258 \mathrm{Eu}^{3+}$ (no specific site sorption), although other compacted particles were observed and were 
259 enriched in Eu. The formation of phases, not observed by XRD, were compatible with $\mathrm{Eu}(\mathrm{OH})_{3}$

260 or $\mathrm{Eu}_{2} \mathrm{SiO}_{3}$, and these same phases were observed at $300^{\circ} \mathrm{C}$ (specific site sorption and chemical 261 reaction).

262 Temperature played a greater role than time in the formation of the europium silicate, as 263 is predicted in thermodynamics and kinetics. However, long reaction times are expected to 264 increase the sorption by specific and chemical reaction mechanisms, even for low reaction 265 temperatures.

\section{Conclusions}

The results demonstrate that two mechanisms are involved in the $\mathrm{Eu}^{3+}$ (trivalent actinide 270 chemical analogue) retention by bentonites: sorption in specific and non-specific sites; and

271 chemical reaction within the bentonite framework. These findings have a direct and significant 272 implication in the mechanism of retention of HLRW by the engineered barrier of DGRs: Not 273 only does it increase the immobilisation capacity of the bentonite, but it also increases the 274 expected stability of the radioactive waste stored in bentonite.

275 Furthermore, the immobilization times can be quantified. The results pointed out that the 276 immobilization of europium by saponite, FEBEX and MX-80 would be completed in 8.5 months 277 at $350^{\circ} \leq \mathrm{T} \leq 200^{\circ} \mathrm{C}$, whereas several years will be needed at $200^{\circ}<\mathrm{T} \leq 80^{\circ} \mathrm{C}$.

279 Acknowledgements.

We are grateful for the financial support from ENRESA (contract $n^{\circ}$ 0079000121) and from DGICYT and 281 FEDER funds (Projects CTQ2010-14874). 


\section{References}

Alba, M.D., Becerro, A.I., Castro, M.A., Perdigon, A.C., 2001. Hydrothermal reactivity of Lusaturated smectites: Part I. A long-range order study. American Mineralogist, 86(1-2): 115-123.

Alba, M.D. et al., 2011. Interaction of Eu-isotopes with saponite as a component of the engineered barrier. Applied Clay Science, 52(3): 253-257.

Alba, M.D., Chain, P., 2005. Interaction between Lu cations and 2 : 1 alumino silicates under hydrothermal treatment. Clays and Clay Minerals, 53(1): 37-44.

Alba, M.D., Chain, P., 2007. Persistence of lutetium disilicate. Applied Geochemistry, 22(1): 192-201.

Alba, M.D., Chain, P., Orta, M.M., 2009a. Chemical reactivity of argillaceous material in engineered barrier Rare earth disilicate formation under subcritical conditions. Applied Clay Science, 43(3-4): 369-375.

Alba, M.D., Chain, P., Orta, M.M., 2009b. Rare-earth disilicate formation under Deep Geological Repository approach conditions. Applied Clay Science, 46(1): 63-68.

Bouby, M., Geckeis, H., Lutzenkirchen, J., Mihai, S., Schafer, T., 2011. Interaction of bentonite colloids with $\mathrm{Cs}, \mathrm{Eu}$, Th and $\mathrm{U}$ in presence of humic acid: A flow field-flow fractionation study. Geochimica Et Cosmochimica Acta, 75(13): 3866-3880.

ENRESA, 2000. Full-scale Engineered Barriers Experiment for a Deep Geological Repository for High Level Radioactive Waste in Crystalline Host Rock, ENRESA, Madrid.

ENRESA, 2006. Full-scale engineered barriers experiment. Publicación Técnica ENRESA, 050/2006, 05-0/2006. ENRESA, Madrid.

Fernandes, M.M., Baeyens, B., Dahn, R., Scheinost, A.C., Bradbury, M.H., 2012. U(VI) sorption on montmorillonite in the absence and presence of carbonate: A macroscopic and microscopic study. Geochimica Et Cosmochimica Acta, 93: 262-277.

Galunin, E., Alba, M.D., Santos, M.J., Abrao, T., Vidal, M., 2010. Lanthanide sorption on smectitic clays in presence of cement leachates. Geochimica Et Cosmochimica Acta, 74(3): 862-875.

Grim, R.E., 1968. Clay Mineralogy. McGraw-Hill Book Company, New York.

Hurtado, S., Villa, M., 2010. An intercomparison of Monte Carlo codes used for in-situ gammaray spectrometry. Radiation Measurements, 45(8): 923-927.

Madsen, F.T., 1998. Clay mineralogical investigations related to nuclear waste disposal. Clay Minerals, 33(1): 109-129.

Miller, A.W., Wang, Y.F., 2012. Radionuclide Interaction with Clays in Dilute and Heavily Compacted Systems: A Critical Review. Environmental Science \& Technology, 46(4): 1981-1994.

Perdigón, A.C., 2002. Estudio del sistema saponita/Lu(NO3)3/H2O en condiciones hidrotérmicas, University of Sevilla, Spain.

Pusch, R., 2006. Engineered barriers. In: Pusch, V.P.a.R. (Ed.), Disposal of Hazardous Waste in Underground Mines. Wessex Institute of Technology, UK, pp. 35-40.

Ravina, I., Low, P.F., 1977. Change of B-Dimension with Swelling of Montmorillonite. Clays and Clay Minerals, 25(3): 201-204.

Savage, D., Chapman, N.A., 1982. Hydrothermal Behavior of Simulated Waste Glass and Waste Rock Interactions under Repository Conditions. Chemical Geology, 36: 59-86.

Sorieul, S. et al., 2008. Radiation-Stability of Smectite. Environmental Science \& Technology, 42(22): 8407-8411. 
329 Stumpf, T., Bauer, A., Coppin, F., Il Kim, J., 2001. Time-resolved laser fluorescence spectroscopy study of the sorption of Cm(III) onto smectite and kaolinite. Environmental Science \& Technology, 35(18): 3691-3694.

Trillo, J.M. et al., 1994. Interaction of Multivalent Cations with Layered Clays - Generation of Lutetium Disilicate Upon Hydrothermal Treatment of Lu-Montmorillonite. Inorganic Chemistry, 33(18): 3861-3862.

Villar, M.V., Gómez-Espina, R., Gutiérrez-Nebot, L., 2012. Basal spacings of smectites in compacted bentonite. Applied Clay Science, 65-66: 95-105.

Warren, B.E., 1941. X-ray diffraction in random layer lattices. Physical Review, 59(9): 693-698. 
Table 1.Characteristics of the clays selected

\begin{tabular}{|c|c|c|c|}
\hline Clays & Structural formula & $\begin{array}{c}\text { Total } \\
\text { charge/ } \\
\text { u.c. }\end{array}$ & $\begin{array}{c}\mathrm{CEC}^{\mathrm{d}} \\
(\mathrm{meq} / 100 \mathrm{~g})\end{array}$ \\
\hline FEBEX $^{\mathrm{a}}$ & $\left(\mathrm{Ca}_{0.5} \mathrm{Na}_{0.08} \mathrm{~K}_{0.11}\right)\left(\mathrm{Si}_{7.78} \mathrm{Al}_{0.22}\right)\left(\mathrm{Al}_{2.78} \mathrm{Fe}^{\mathrm{III}}{ }_{0.33} \mathrm{Fe}_{0.02}^{\mathrm{II}} \mathrm{Mg}_{0.81}\right) \mathrm{O}_{20}(\mathrm{OH})_{4}$ & 1.19 & 158.2 \\
\hline $\mathrm{MX}-80^{\mathrm{b}}$ & $\left(\mathrm{Na}_{0.36} \mathrm{Ca}_{0.20}\right)\left(\mathrm{Si}_{7.96} \mathrm{Al}_{0.04}\right)\left(\mathrm{Al}_{3.1} \mathrm{Mg}_{0.56} \mathrm{Fe}_{0.18}^{\mathrm{III}} \mathrm{Fe}_{0.16}^{\mathrm{II}}\right) \mathrm{O}_{20}(\mathrm{OH})_{4}$ & 0.76 & 102.1 \\
\hline Saponite $^{c}$ & $\mathrm{Na}_{0.8}\left(\mathrm{Si}_{7.2} \mathrm{Al}_{0.8}\right)\left(\mathrm{Mg}_{5.79} \mathrm{Fe}_{0.14}\right) \mathrm{O}_{20}(\mathrm{OH})_{4}$ & 0.80 & 103.0 \\
\hline
\end{tabular}

Table 2.Temperatures and times used in the hydrothermal treatments with FEBEX and MX-80 bentonite and europium. Stripes correspond to solutions where no radioactive tracer was added

\begin{tabular}{|c|c|c|c|c|c|c|c|c|c|}
\hline \multirow{2}{*}{$\mathrm{T}\left({ }^{\circ} \mathrm{C}\right)$} & \multicolumn{9}{|c|}{ Time (days) } \\
\hline & 0 & 2.2 & 4.5 & 9 & 28 & 35 & 56 & 63 & 120 \\
\hline 80 & & & & & & & & & \\
\hline 150 & & & & & & & & & \\
\hline 300 & & & & & & & & & \\
\hline
\end{tabular}


Table 3. Kinetics parameters of the europium sorption by clays.

\begin{tabular}{|c|c|c|c|}
\hline \multirow{2}{*}{$\mathrm{T}\left({ }^{\circ} \mathrm{C}\right)$} & saponite & FEBEX & MX-80 \\
\hline & \multicolumn{3}{|c|}{$\mathrm{k} \cdot 10^{-3}\left(\right.$ days $\left.^{-1}\right)$} \\
\hline 350 & $14 \pm 5$ & & \\
\hline 300 & & $14 \pm 3$ & $11 \pm 6$ \\
\hline 200 & $11.9 \pm 0.1$ & & \\
\hline 150 & $3.6 \pm 1.5$ & $3 \pm 1$ & $1.5 \pm 1.2$ \\
\hline 80 & $2.4 \pm 2.0$ & $1.0 \pm 0.1$ & $2 \pm 1$ \\
\hline $\mathrm{T}\left({ }^{\circ} \mathrm{C}\right)$ & & $\mathrm{T}_{1 / 2}$ (days) & \\
\hline 350 & $50 \pm 2$ & & \\
\hline 300 & & $50 \pm 10$ & $60 \pm 30$ \\
\hline 200 & $58.2 \pm 0.5$ & & \\
\hline 150 & $190 \pm 80$ & $230 \pm 80$ & $460 \pm 300$ \\
\hline 80 & $290 \pm 240$ & $690 \pm 70$ & $350 \pm 170$ \\
\hline $\mathrm{T}\left({ }^{\circ} \mathrm{C}\right)$ & & ssion coeffici & \\
\hline 350 & 0.9959 & & \\
\hline 300 & & 0.7669 & 0.6598 \\
\hline 200 & 0.9951 & & \\
\hline 150 & 0.2912 & 0.9708 & 0.8770 \\
\hline 80 & 0.4453 & 0.9826 & 0.0961 \\
\hline
\end{tabular}

345 Fig. 1. Amount of stable europium retained in the solid phase in FEBEX, MX-80 and saponite.

346 The solid line indicates the CEC of FEBEX, and the dashed line the CEC of MX-80 and saponite.

347 Red columns correspond to FEBEX results, blue columns correspond to MX-80 and the grid 348 pattern corresponds to saponite. Blank results mean that no experiment was performed for that 349 reaction time. 
351 Fig. 2. ${ }^{152} \mathrm{Eu}(\mathrm{Bq})$ in the liquid phase after the hydrothermal treatment (unreacted $\left.{ }^{152} \mathrm{Eu}\right)$ with 352 saponite, FEBEX and MX-80 versus time at (a) $300{ }^{\circ} \mathrm{C}$, (b) $150{ }^{\circ} \mathrm{C}$, and (c) $80{ }^{\circ} \mathrm{C}$, data were 353 fitted to an exponential function. Initial ${ }^{152} \mathrm{Eu}$ added was $9 \mathrm{~Bq}$. Red corresponds to FEBEX 354 results, blue to MX-80, and black to saponite.

356 Fig. 3. XRD diagrams of bentonite FEBEX: (a) before treatment; (b) after the hydrothermal 357 treatments at $300^{\circ} \mathrm{C}$ for $0 \mathrm{~h}$; (c) for 2.25 days; (d) for 4.5 days; (e) for 9 days; and (f) for 11 358 days. $\mathrm{E}=\mathrm{EuSiO}_{3}(\mathrm{PDF} 35-297), \mathrm{oh}=\mathrm{Eu}(\mathrm{OH})_{3}(\mathrm{PDF} 83-2305), \mathrm{a}=\mathrm{Na}_{8}\left(\mathrm{AlSiO}_{4}\right)_{6}(\mathrm{OH})_{2}(\mathrm{PDF} 40-$ 359 0100) and q=quartz (PDF 2-458).

361 Fig. 4. XRD diagrams of bentonite MX-80: (a) before treatment; (b) after the hydrothermal 362 treatments at $300^{\circ} \mathrm{C}$ for $0 \mathrm{~h}$; (c) for 2.25 days; (d) for 4.5 days; and (e) for 9 days. $\mathrm{E}=\mathrm{EuSiO}_{3}$ 363 (PDF 35-297) and q=quartz (PDF 2-458).

365 Fig. 5. XRD diagrams of bentonite FEBEX (left) and bentonite MX-80 (right): (a) before 366 treatment; (b) after the hydrothermal treatments at $80^{\circ} \mathrm{C}$ for 63 days; and (c) at $150^{\circ} \mathrm{C}$ for 56 367 days.

369 Fig. 6. SEM/EDX of bentonite FEBEX (left) and MX-80 (right) after hydrothermal treatment at $370150^{\circ} \mathrm{C}$ for 28 days. 

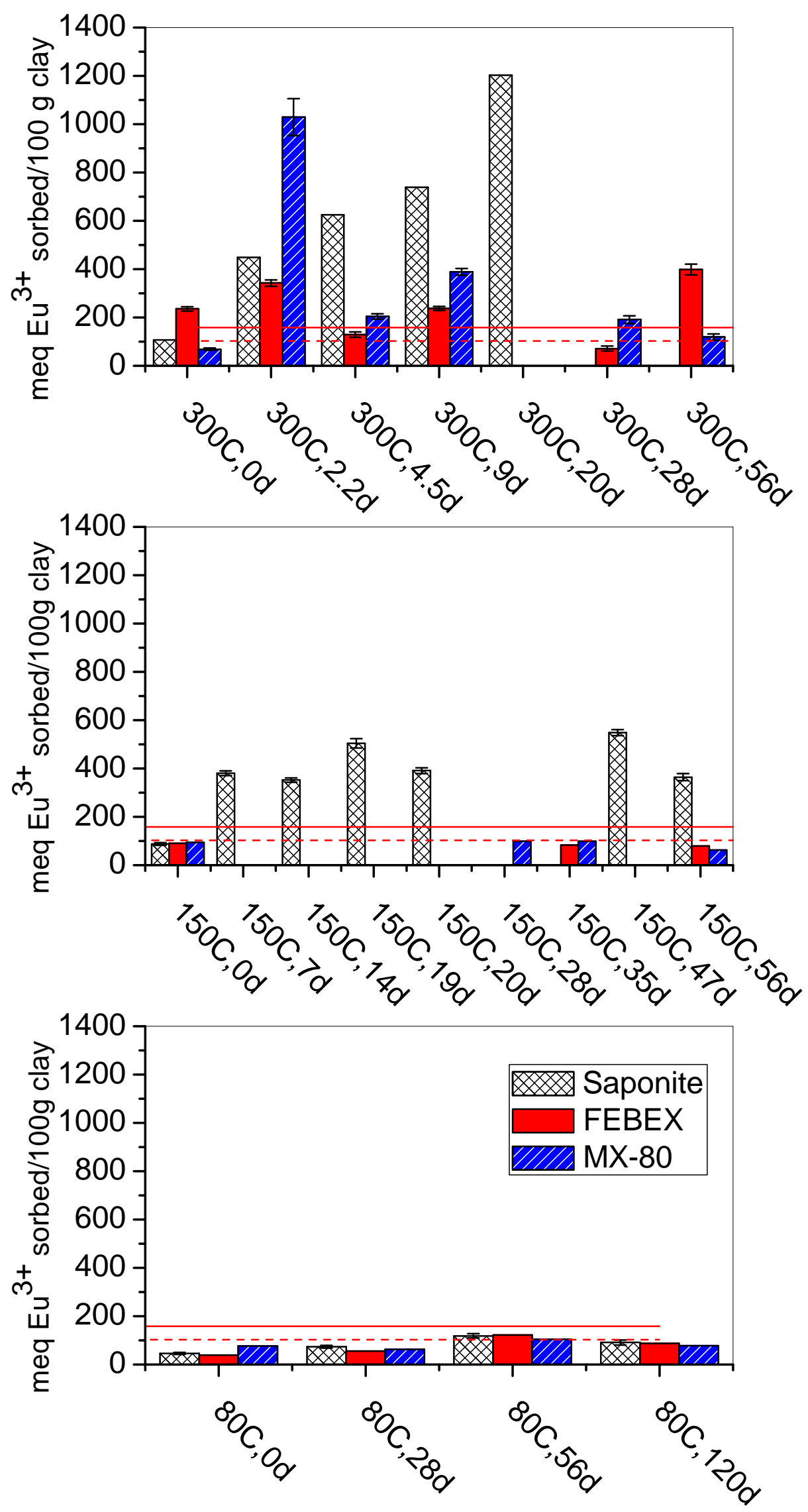

Hydrothermal treatment 

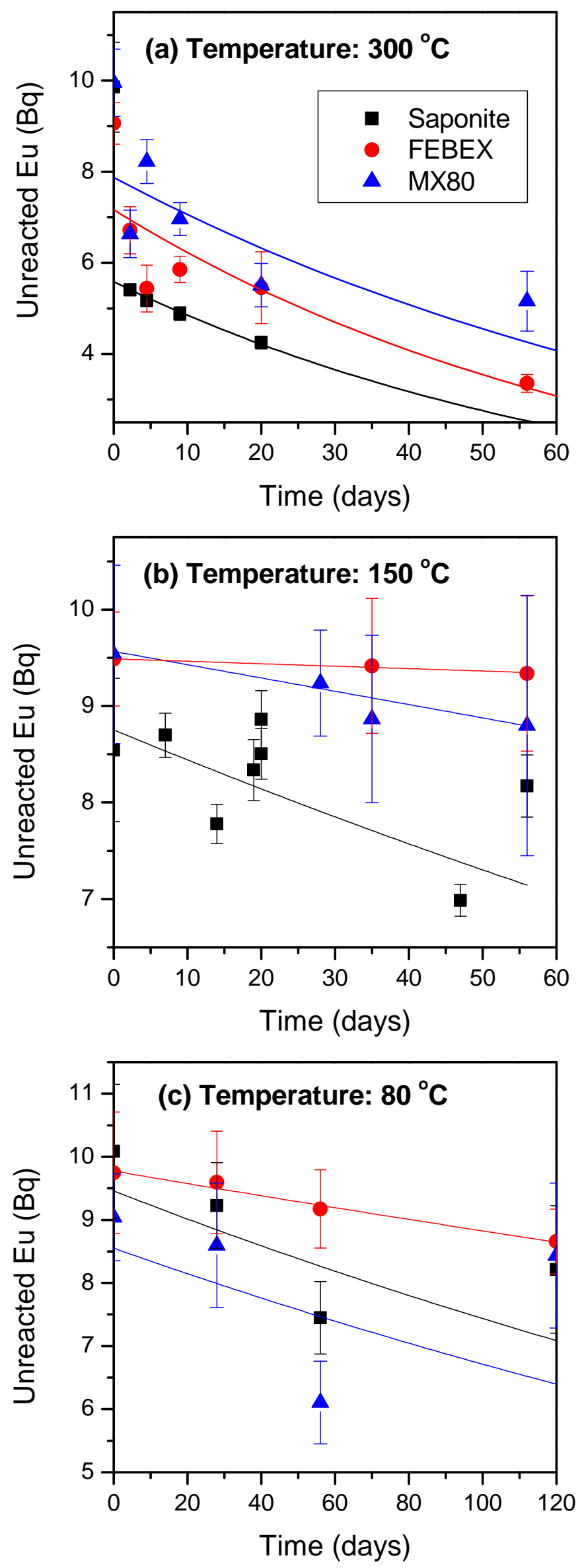

$372 \quad$ Figure 2 


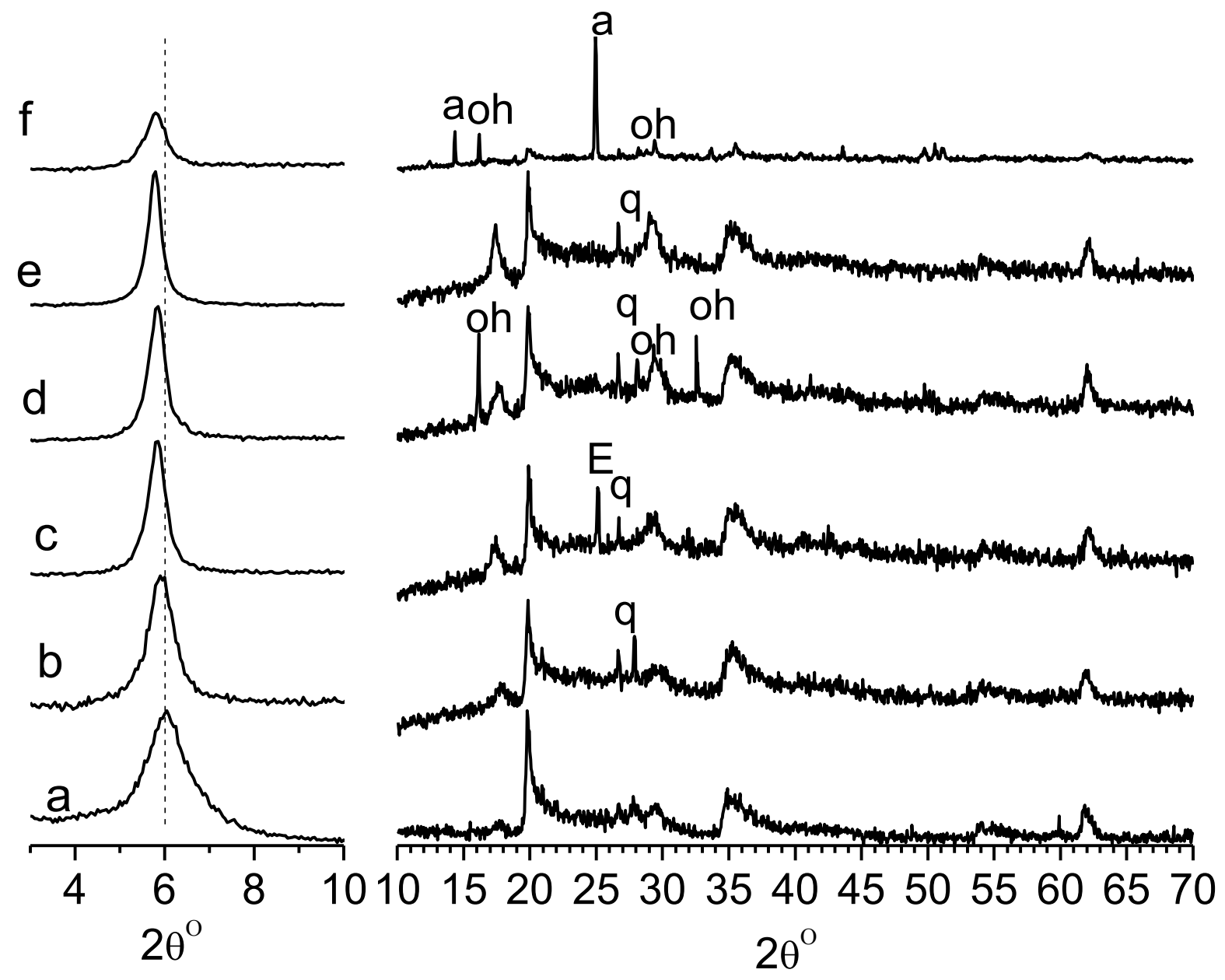

$380 \quad$ Figure 3 

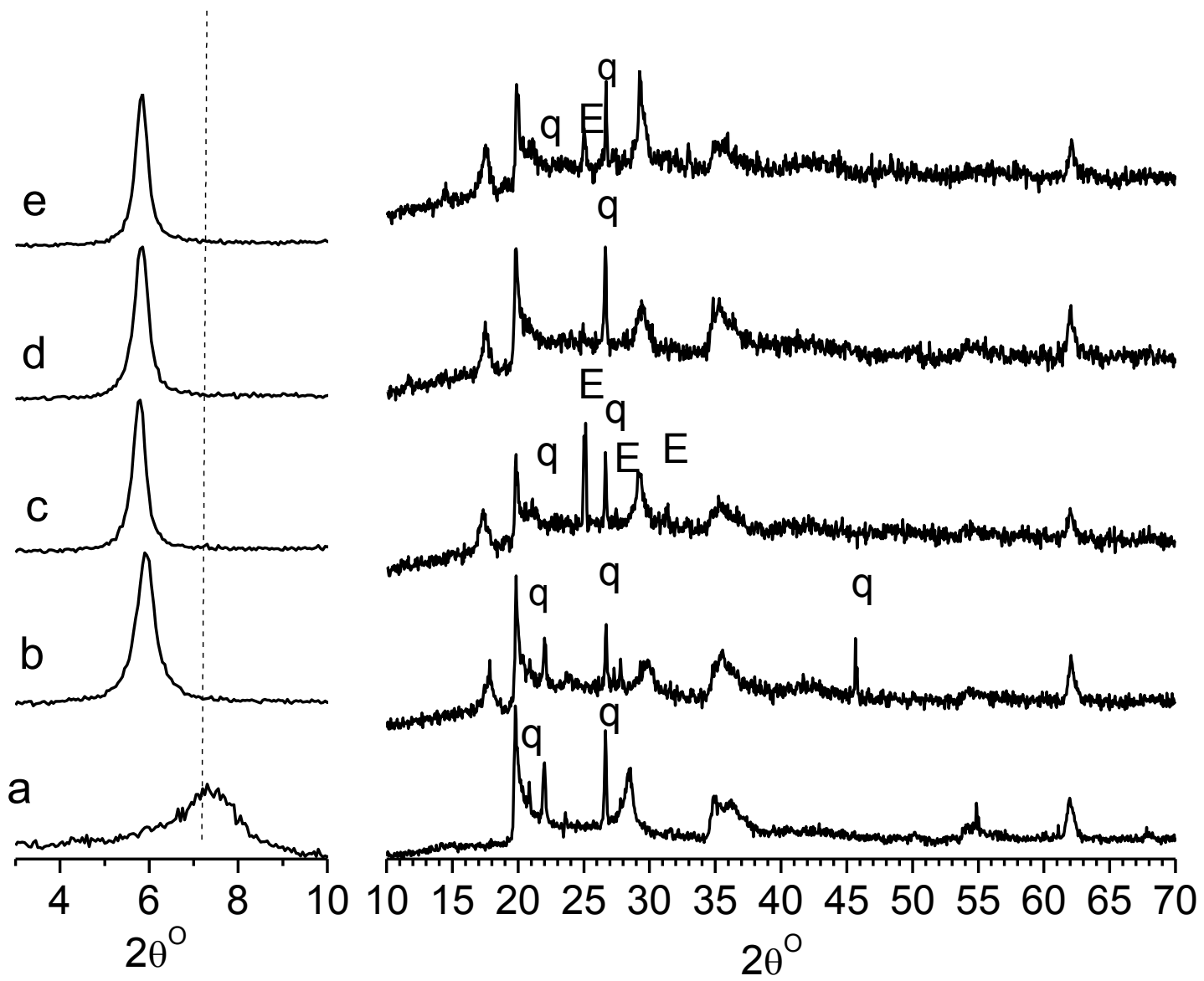

382

383

$384 \quad$ Figure 4 


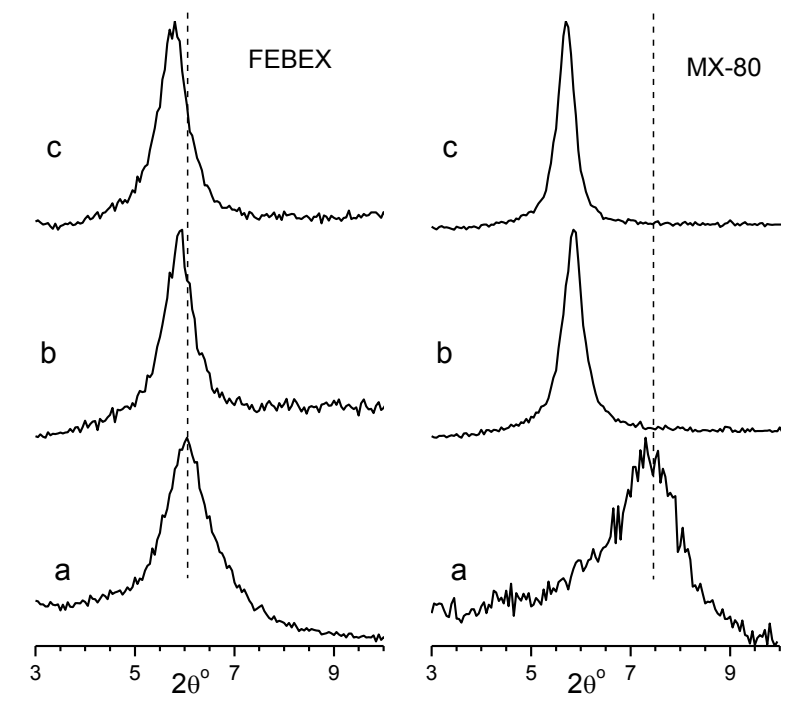

385 Figure 5

386 


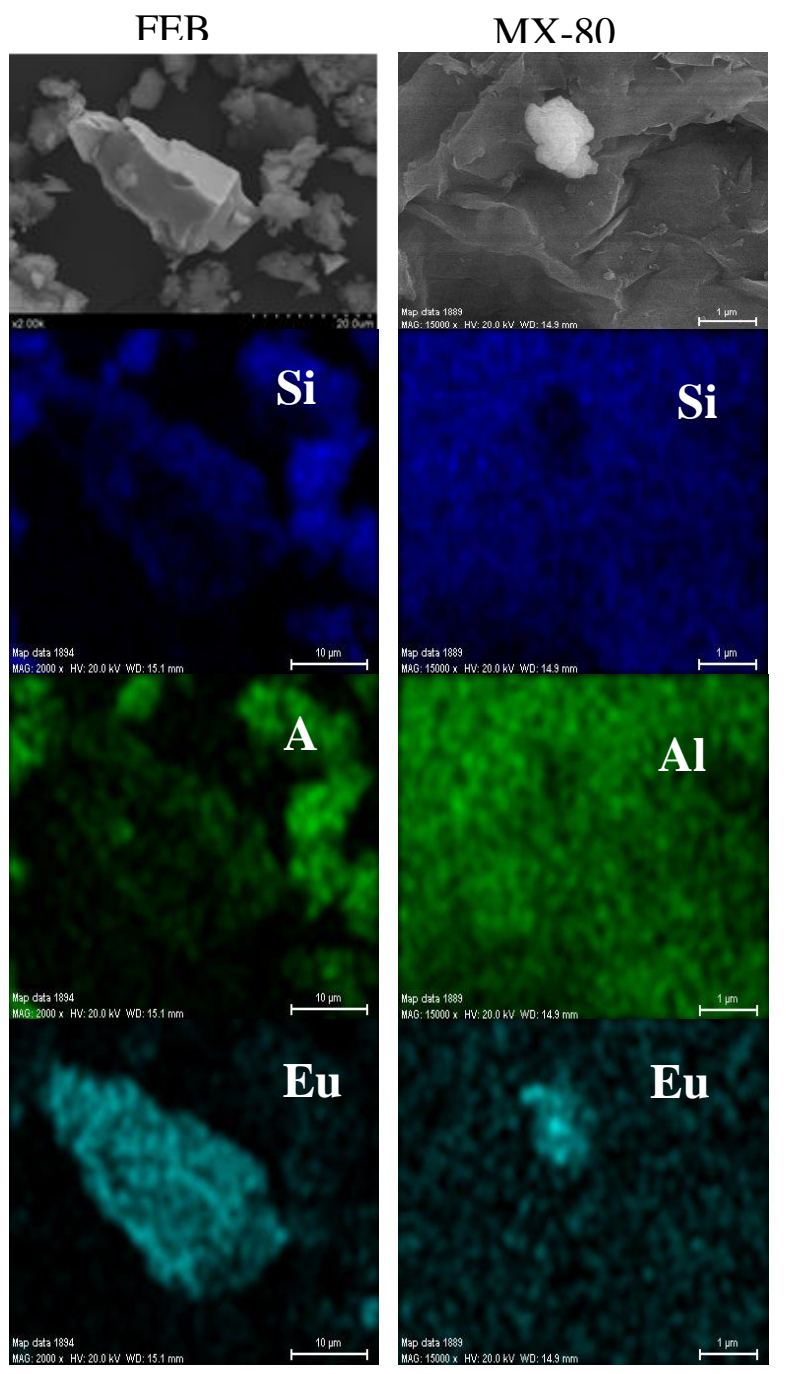

389 Figure 6

390 